\title{
DO MONETARY AGGREGATES BELONG IN A MONETARY MODEL? EVIDENCE FROM THE UK
}

\author{
Mehmet Ezer \\ Department of Economics, Business, and Accounting, Randolph-Macon College, Ashland VA, USA. \\ Email: mehmetezer@rmc.edu
}

\begin{abstract}
Conventional monetary models focus on interest rates and omit monetary aggregates from policy discussions. This paper examines whether augmenting the measure of monetary policy with monetary aggregates helps determine more robust links between policy and economic fluctuations. After constructing the Divisia money index for the UK, I employ structural vector autoregression to identify two different UK monetary policy regimes. Inclusion of this (correct) measure of money and disentangling the money supply from demand resolve the price and liquidity puzzles. The results point to the informational content embedded in monetary aggregates, suggesting they should be taken into account in evaluations of monetary policy.
\end{abstract}

Keywords: Time series models; Monetary policy; Central bank policies.

JEL Classifications: C21; E52; E58.

Article history:

Received : October 02, 2019

Revised : : December 26, 2019

Accepted : January 7, 2020

Available online : January 10, 2020

https://doi.org/10.21098/bemp.v22i4.1184 


\section{INTRODUCTION}

Monetary policy is one of the most important tools economic policymakers use while attempting to shape the economy. Therefore, it is crucial to successfully gauge its stance and understand the mechanisms through which it affects the variables in the economy.

Friedman and Schwartz (1963) document evidence that shows not only that money stock is procyclical, but also its movements lead the movements of output, suggesting a causal relation between these two variables. Later studies, however, show a weakening correlation structure between money stock and output. Combined with the expanding real business cycle literature, which attributes fluctuations in the economy to real variables, this weakening correlation structure has diminished interest in analyzing the behavior of money stock. New Keynesian models that were developed later ${ }^{1}$ study monetary policy and its effects by focusing on the role of interest rates, particularly the short-term nominal interest rate, in line with empirical studies conducted in the 1980s and 1990s. ${ }^{2}$ However, the transmission mechanism of monetary policy consists of various channels, and short-term nominal interest rates play only an indirect role in affecting output levels. ${ }^{3}$

Money stock could be an alternative or complementary measure to shortterm nominal interest rates in understanding the stance and role of monetary policy. However, the challenge is to disentangle the money demand from the money supply, since they together determine the level of the money stock. As the proponents of real business cycle theory observe, the money stock itself could be affected by movements in output, creating reverse causality where the business cycle drives the money stock, rather than vice versa. ${ }^{4}$

In a recent study, Belongia and Ireland (2016) show that monetary aggregates have the ability to explain aggregate fluctuations in the US economy, but only when properly measured. "Proper measurement" requires the use of Divisia aggregates instead of money. The authors first show that the correlation structure suggested by Friedman and Schwartz (1963) is still used. By utilizing a structural vector autoregression (SVAR) model, Belongia and Ireland (2016) draw tight links between monetary policy and economic fluctuations. The user cost (price dual) series of their preferred money stock measure, Divisia aggregates, enables them to disentangle the behavior of money demand from that of the money supply. Their analysis quantifies the contribution of monetary policy to instability in the US economy between 1967 and 2013 and suggests that monetary aggregates should be taken into account while evaluating the stance of monetary policy.

Three questions naturally arise: is there a discrepancy between the simplesum and Divisia quantities for other economies? Is there further evidence that the monetary aggregates should be taken into account to understand the stance of the monetary policy? Can augmenting the measure of monetary policy with monetary aggregates help to draw more robust links between monetary policy and economic fluctuations?

\footnotetext{
1 Woodford (2003) provides examples of such models.

2 See Estrella and Mishkin (1997) and Stock and Watson (1999), for example.

3 Mishkin (2007) summarizes the channels through which monetary policy affects output.

4 See King and Plosser (1984) and Plosser (1989).
} 
Following Barnett's (1980) critique, many monetary authorities started calculating Divisia indexes, as well as simple-sum measures of money. However, these measures are mostly meant only for internal use. The Bank of England is one of the few monetary authorities that makes Divisia indexes publicly available, and this enables us to study the questions at hand for the UK economy. However, the publicly available data for the UK is not adjusted for breaks caused by the reclassification of financial institutions. Our study is the first to construct a Divisia money index for the UK to employ SVAR analysis and answer the aforementioned questions.

We first construct the break-adjusted Divisia money index data for the UK. Then, we conduct SVAR analysis à la Belongia and Ireland (2016), which allows us to estimate the monetary policy rules and money demand equations. Such an analysis determines which type of monetary policy rule better fits the data. Alternatives are a Taylor rule without money (standard in most New Keynesian models), a Taylor rule with money, and a money-interest rate rule similar to what Leeper and Roush (2003) and Sims and Zha (2006) advocate. Our analysis favors the use of the interest rate-money rule as the preferred formulation for the conduct of monetary policy in the UK. Furthermore, measuring the money stock using the Divisia money index and disentangling the money supply from the money demand resolves the price and liquidity puzzles. Our study shows that the reaction of the interest rate to the stock of money was quite strong in the UK for the period between 1978 and 1990, but this relation weakens from 1993 onward.

The remainder of this paper is organized as follows. Section II reviews the literature. Section III explains how the Divisia index is constructed and compares it with a simple-sum monetary aggregate. Section IV presents the model and the methodology. Section V provides the results from SVAR analysis. The last section concludes the paper.

\section{LITERATURE REVIEW}

Interest in analyzing the behavior of money stock diminished in the 1980s and 1990s. Seminal studies by Bernanke and Blinder (1992), Estrella and Mishkin (1997), and Stock and Watson (1999) attribute a less significant role to money stock. Bernanke and Blinder (1992) argue that the interest rate on federal funds is a good indicator of monetary policy actions and is therefore informative about the future movements of real macroeconomic variables. The role of money is minimized once the federal funds rate is introduced into the empirical framework. Estrella and Mishkin (1997) suggest that monetary aggregates can play a role as information variables, indicators of policy actions, and instruments in a policy rule. However, these roles would require a stable relation between the aggregates and the final policy targets. By studying US data from 1979 to 1995, the authors show that such a relation did not exist in that period. Stock and Watson (1999) study inflation forecasts and suggest no gains from including the money supply in their analysis. These studies suggest that focusing on the federal funds rate suffices to study monetary policy.

Studies show that the quantity of money contains valuable information; however, obtaining this information requires differentiating the money supply 
and the money demand, which is not a straightforward task. Hendrickson (2017) argues that deviations between money demand and money supply are an important source of economic fluctuations. Moreover, the author shows that shocks to the monetary base play a significantly more important role than money demand shocks in terms of generating instability. Belongia and Ireland (2019) identify a stable money demand function from 1967 through 2019 by using Divisia aggregates, which suggests that an aggregate quantity of money can play a role in monetary policy when properly measured.

There is a rapidly growing literature focusing on the "right way" of measuring the amount of money, since the "wrong measurement" leads to qualitatively misleading results. Belongia (1996) highlights the importance of choosing the right monetary index. The author replicates five studies analyzing the effects of money on aggregate activity and shows that, in four of the five cases, the qualitative inference in the original study is reversed when the simple-sum monetary aggregate is replaced by the corresponding Divisia index. Hendrickson (2014) provides further evidence on the Divisia index being a better measure of money stock. The author suggests that the conclusions of previous studies arguing that monetary aggregates are not useful as an intermediate target for monetary policy or as an information variable could have been driven by mismeasurement. In a recent study, Anderson et al. (2019) construct Divisia indexes for the United States at various levels of aggregation from the late 1940s through 1967. Merging their data with the Divisia index series published by the Center for Financial Stability means that researchers now have access to consistent Divisia money measures covering nearly all of the post-war period. Drake et al. (2000) construct so-called wide Divisia monetary aggregates that include risky assets such as mutual funds, equities, and bonds, and show that such wide measures have good leading indicator properties in the context of Granger causality tests. All of these studies advocate the use of a Divisia index rather than simple-sum measures of money.

When the right measures of money stock are employed, the quantity of money is shown to have important macroeconomic properties. Dery and Serletis (2019) examine the cyclical behavior of Divisia money index and find support for a monetary effect on the business cycle. Their findings highlight the importance of using broad Divisia monetary aggregates. Belongia and Ireland (2015) show that Divisia measures of money help in forecasting the movements of key macroeconomic variables. Furthermore, the statistical fit of SVAR improves significantly when these measures of money are included to identify monetary policy shocks. The results of Belongia and Ireland challenge the adequacy of conventional models, which focus solely on interest rates. Darvas (2015) creates a new data set based on euro area Divisia monetary aggregates. By estimating the responses to money and interest rate shocks in the euro area using SVAR, Darvas provides supporting evidence regarding the usefulness of Divisia monetary aggregates in assessing the impacts of monetary policy. Keating et al. (2019) propose abandoning the federal funds rate as the policy indicator and using, instead, broad Divisia monetary aggregates. This approach results in monetary policy effects that are qualitatively similar to those of the case in which the federal funds rate is the policy indicator; furthermore, it allows for the measurement of the effects of monetary policy, even if the federal funds rate hits a zero lower bound. 
In light of these studies, we construct a Divisia money index for the UK and conduct SVAR analysis to estimate the monetary policy rules and money demand equations. We determine which type of monetary policy rule better fits the data. Our analysis suggests the use of the interest rate-money rule when formulating monetary policy in the UK. Furthermore, we examine whether augmenting the measure of monetary policy with monetary aggregates helps in drawing more robust links between policy and economic fluctuations.

\section{CONSTRUCTION OF THE DIVISIA INDEX}

Conventional simple-sum monetary aggregates are obtained by summing all the monetary assets included in an aggregate. Divisia indexes, however, acknowledge that the components of monetary aggregates are imperfect substitutes for each other, and, hence, the growth rates of these indexes are calculated by weighting the growth rates of the components by their average expenditure shares over two consecutive periods. These expenditure shares are based on the components' user cost, which is measured as the difference between a benchmark interest rate and their own interest rate.

The UK money stock is split between three sectors: household, private nonfinancial corporate, and other financial corporate. Following Hancock (2005), who shows that financial corporations' Divisia data have high variance and that their volatility could be telling us little about near-term spending plans, this study uses only household and private nonfinancial corporate sectors' monetary assets to construct the index.

Monetary data for the UK must be adjusted for breaks that arise when building societies change classifications to become banks. Hancock (2005) explains that leaving data unadjusted would lead to reports of large flows out of building societies and into banks. As Bissoondeeal et al. (2010) point out, break-adjusted level data take this fact into account and adjust the data by reallocating past deposits at a building society that subsequently became a bank into bank series. Therefore, the analysis uses non-break-adjusted level data and break-adjusted flows to correctly weight each component asset.

The variable $M_{i, t}$ denotes the unadjusted amounts outstanding (unadjusted level) of the $i$ th monetary asset for period $t, \Delta M_{i, t}$ is the difference between successive amounts outstanding, and $\Delta M_{i, t}^{B A}$ denotes the break-adjusted flows for the $i$ th monetary asset for period $t$. The user cost of the $i$ th asset is $u_{i, t}=\left(r_{B, t}-r_{i, t}\right) /\left(1+r_{B, t}\right)$, where $r_{i, t}$ is the own rate of the asset and $r_{B, t}$ is the rate of return on a nonmonetary benchmark asset. Consequently, the expenditure shares for each asset are calculated as

$$
W_{i, t}=\frac{u_{i, t} M_{i, t}}{\sum_{j=1}^{N} u_{j, t} M_{j, t}}
$$


The Bank of England uses the following formula to compute its Divisia index, $D_{t}:$

$$
\frac{D_{t}-D_{t-1}}{D_{t-1}}=\sum_{i=1}^{N} \frac{1}{2}\left(W_{i, t}+W_{i, t-1}\right) \frac{\Delta M_{i, t-1}^{B A}}{M_{i, t-1}}
$$

which means that the growth rate of the Divisia index weights the component growth rates by their average shares. Using the fact that the average shares sum to one, the above equation is rearranged to obtain the following iterative formula to compute the level of the Divisia index:

$$
D_{t}=D_{t-1} \sum_{i=1}^{N} \frac{1}{2}\left(W_{i, t}+W_{i, t-1}\right) \frac{M_{i, t-1}+\Delta M_{i, t-1}^{B A}}{M_{i, t-1}}
$$

The Bank of England's household and private nonfinancial corporate sector Divisia index includes the following components as of January 2008:

- Notes and coins

- Non-interest-bearing deposits

- Interest-bearing bank sight deposits

- Interest-bearing bank time deposits

- Interest-bearing building society sight deposits

- Interest-bearing building society time deposits

The Bank of England's household sector data also include tax-exempt special savings accounts and individual savings accounts, introduced in 1991 and 1999, respectively. These assets are not incorporated into the index under construction, since they are primarily a form of savings for households, as Hancock (2005) explains.

The components constituting the Divisia index change over time. Interestbearing deposits of the private nonfinancial corporate sector at building societies are introduced to the index in July 1996. Non-interest-bearing deposits in both sectors have been included in the index since July 1997. Since January 1999, household sector deposits at building societies have been split into two categories, with instant access and notice accounts. The last change for building society data occurred in January 2008, when the deposits in building societies started being published as sight and time deposits for all sectors.

While calculating the user costs of the components of the Divisia index, we use the quoted interest rates of assets until 1999, and the effective rates that year onward. ${ }^{5}$ As for the benchmark rate, we follow Bissoondeeal et al. (2010) and adopt an envelope approach similar to that used by the Bank of England. A total of 250 basis points are added to the three-month Treasury bill rate, which is then compared with the interest rates of the assets included in the Divisia index. Every period, the highest rate provides the benchmark rate for the calculations.

5 See the explanatory notes for sectoral deposits and Divisia money at the Bank of England's website (http://www. bankofengland.co.uk/statistics/Pages/iadb/notesiadb/divisia.aspx). 
Figure 1 plots the year-over-year growth rates of the Divisia and simple-sum series. The two series move in the same direction. However, the discrepancy between them can become quite large in certain years. Figure 2 shows that the difference between the year-over-year growth rates of the simple sum and Divisia money can be as large as 10 percentage points. This discrepancy highlights the importance of using the correct measure for money and indicates that use of the simple-sum measures of money instead of the Divisia index can lead to misleading results.

Figure 1.

Divisia and Simple-sum Year-over-year Growth Rate Comparison in Percentages

This graph shows the year-over-year growth rates for Divisia and simple-sum monetary aggregates in percentages. (1978Q1 to 2013Q3)

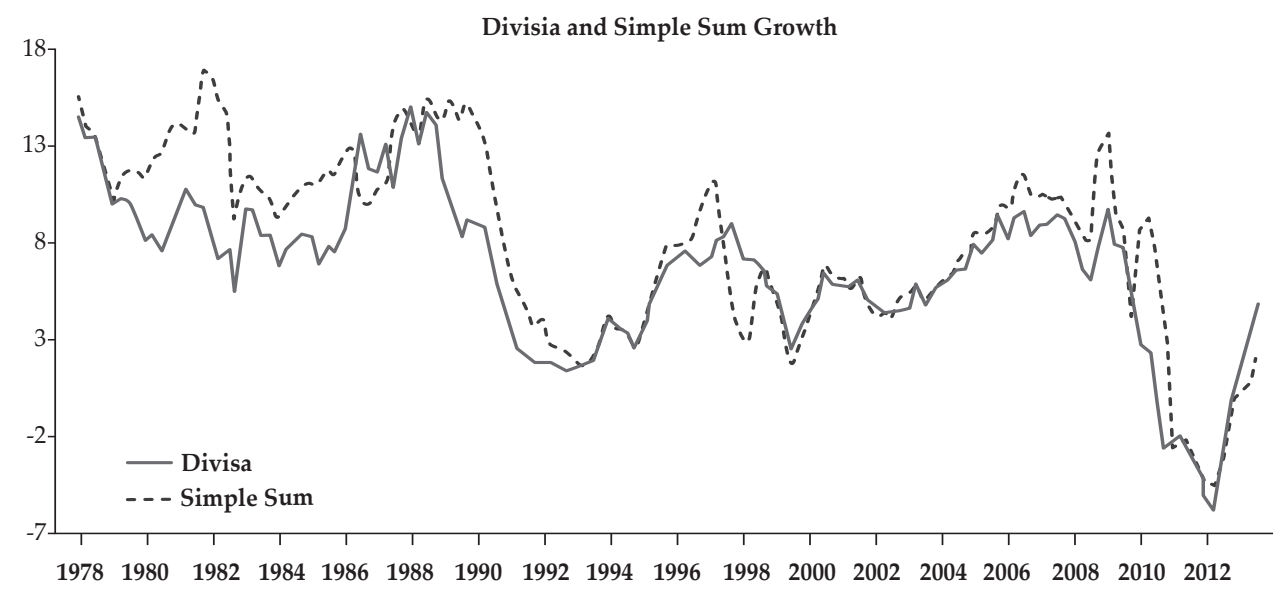

Figure 2.

Differences in Year-over-year Growth Rates of Divisia and Simple-sum Monetary Aggregates, in Percentage Points

This graph shows the differences in year-over-year growth rates of Divisia and simple-sum monetary aggregates in percentages. (1978Q1 to 2013Q3).

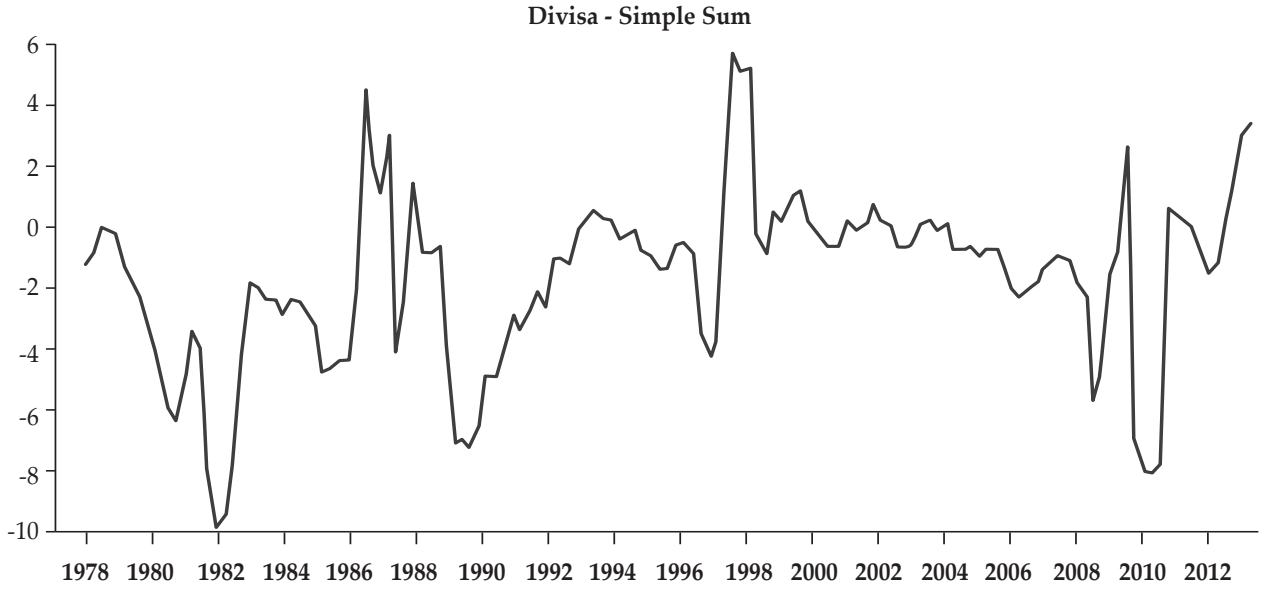




\section{MODEL AND METHODOLOGY}

Following Belongia and Ireland (2016), a vector autoregression (VAR) model is used to describe the behavior of six variables: the output $Y_{t}$, measured by the real GDP; the price level $P_{t}$, measured by the GDP deflator; money $M_{t}$ measured by the Divisia index; the short-term nominal interest rate $R_{t}$, measured by the official bank rate; the user cost of money $U_{t}$, given by $R_{t}-R_{t}^{M}$, where $R_{t}^{M}$ is the weighted average return on different components of money; and, finally, commodity prices $C P_{t^{\prime}}$ measured by the CRB BLS spot index. The output, price levels, money, and commodity prices enter our model in logarithmic form, whereas the short-term nominal interest rate and Divisia user cost are expressed in terms of decimals. Stacking the variables at each period into the $6 \times 1$ vector

$$
X_{t}=\left[P_{t} Y_{t} C P_{t} R_{t} M_{t} U_{t}\right]^{\prime}
$$

we can build a structural model of the form

$$
A X_{t}=\mu+\sum_{j=1}^{q} \Phi_{j} X_{t-j}+\Sigma \varepsilon_{t}
$$

where $A$ is a $6 \times 6$ matrix of coefficients with ones along the diagonal; $\mu$ is a $6 \times 1$ vector of constant terms; each $\Phi_{i^{\prime}} j=1,2, \ldots, q$, is a $6 \times 6$ matrix of slope coefficients; $\Sigma$ is a $6 \times 6$ matrix with the standard deviations of the structural disturbances along its diagonal, and zero elsewhere; and $\varepsilon_{t}$ is a $6 \times 1$ vector of serially and mutually uncorrelated structural disturbances, normally distributed, with zero means, and

$$
E \varepsilon_{t} \varepsilon_{t}^{\prime}=I
$$

The reduced form associated with Equations (2) and (3) is

$$
X_{t}=v+\sum_{j=1}^{q} \Gamma_{j} X_{t-j}+\eta_{t}
$$

where the constant term $v=A^{-1} \mu$ is $6 \times 1$; each $\Gamma_{j}=A^{-1} \Phi_{i^{\prime}} j=1,2, \ldots, q$, is a $6 \times 6$ matrix of slope coefficients; and the $6 \times 1$ vector of zero mean disturbances $\eta_{t}$ is such that

$$
E \eta_{t} \eta_{t}^{\prime}=\Omega
$$

The structural and reduced-form disturbances are linked via

$$
A^{-1} \Sigma \varepsilon_{t}=\eta_{t}
$$

such that

$$
A^{-1} \Sigma \Sigma^{\prime}\left(A^{-1}\right)^{\prime} \varepsilon_{t}=\Omega
$$


Since the covariance matrix $\Omega$ for the reduced-form innovations has 21 distinct elements, at least 15 restrictions must be imposed on the 36 elements of $A$ and $\Sigma$ that have not been normalized to equal to zero or one, to identify the structural disturbances from the information in reduced form. To solve the identification problem, we follow Sims (1980) and assume that $A$ is lower triangular. If the variables are ordered as in Equation (1), then the fourth element of $\varepsilon_{t}$ can be interpreted as the monetary policy shock $\varepsilon_{t}^{m p}$. This suggests that the aggregate price level, output, and commodity prices respond with a lag to monetary policy, and the Bank of England adjusts the official bank rate contemporaneously in response to movements in these variables according to the equation

$$
a_{41} P_{t}+a_{42} Y_{t}+a_{43} C P_{t}+R_{t}=\sigma_{44} \varepsilon_{t}^{m p}
$$

where $a_{i j}$ denotes the coefficient from row $i$ and column $j$ of $A$ and $\sigma_{44}$ is the fourth element along the diagonal of $\Sigma$. The terms involving the constant $\mu$ and lagged values $X_{t-j}$ in Equation (2) are suppressed in Equation (7) to focus on the contemporaneous links between the variables. Similarly, the fifth row of the triangular model yields the equation

$$
a_{51} P_{t}+a_{52} Y_{t}+a_{53} C P_{t}+a_{54} R_{t}+M_{t}=\sigma_{55} \varepsilon_{t}^{m d}
$$

which can be interpreted as a money demand equation, linking the money demand to the price level, the output, commodity prices, and the short-term interest rate as the opportunity cost of holding money. Equation (7) depicts the official bank rate being targeted without reference to the money stock, and (8) assumes that the money stock expands and contracts to accommodate shifts in money demand for the given interest rate.

We use a second, alternative identification scheme in which the money stock plays a larger role in the making and transmission of monetary policy. In this scheme, $A$ is allowed to take the nontriangular form

$$
\left[\begin{array}{cccccc}
1 & 0 & 0 & 0 & 0 & 0 \\
a_{21} & 1 & 0 & 0 & 0 & 0 \\
a_{31} & a_{32} & a_{33} & a_{34} & a_{35} & a_{36} \\
0 & 0 & 0 & 1 & a_{45} & 0 \\
-1 & a_{52} & 0 & 0 & 1 & a_{56} \\
-a_{65} & 0 & 0 & a_{64} & a_{65} & 1
\end{array}\right]
$$

In this alternative identification, the first two rows are similar to the triangular identification in which the aggregate price level and output respond to the other shocks hitting the economy with a lag of one period. Row three of Equation (9) indicate that the commodity prices are assumed to react immediately to every shock to the economy. 
In particular, the monetary system is modeled by the last three rows of Equation (9). The monetary policy rule described by the fourth row is similar to the rules employed by Sims (1986) and Leeper and Roush (2003):

$$
R_{t}+a_{45} M_{t}=\sigma_{44} \varepsilon_{t}^{m p}
$$

This monetary policy rule associates a monetary policy shock with simultaneous movements in the interest rate and the nominal money supply. For a positive $\sigma_{45}$ coefficient, such a rule associates monetary policy tightening with an immediate increase in interest rates and a decrease in the money stock.

This policy rule can be expanded so that it includes prices and output, which would mean that the interest rate immediately responds to changes not only in the money supply, but also in the price level and output, as follows:

$$
a_{41} P_{t}+a_{42} Y_{t}+R_{t}+a_{45} M_{t}=\sigma_{44} \varepsilon_{t}^{m p}
$$

The fifth row in Equation (9) suggests a money demand equation of the form

$$
a_{52} Y_{t}+\left(M_{t}-P_{t}\right)+a_{56} U_{t}=\sigma_{55} \varepsilon_{t}^{m d}
$$

which links the real value of the Divisia index to the output and the user cost as the associated price.

The behavior of private financial institutions can be characterized by the sixth row of Equation (9):

$$
a_{64} R_{t}+a_{65}\left(M_{t}-P_{t}\right)+U_{t}=\sigma_{66} \varepsilon_{t}^{m s}
$$

which suggests that both the official bank rate and the quantity of real monetary services created are passed along to user costs.

We employ the maximum likelihood method to estimate the described SVAR model as outlined by Hamilton (1994) and Lutkepohl (2006). Fully efficient estimates of the reduced-form constant and slope coefficients in Equation (4) can be obtained by applying ordinary least squares, equation by equation. Then, the estimate of the reduced-form innovation covariance matrix must be computed as suggested by Equation (5):

$$
\widehat{\Omega}=(1 / T) \sum_{t=1}^{T} \eta_{t} \eta_{t}{ }^{\prime}
$$

By maximizing the following concentrated log-likelihood function, the following estimates are obtained for the parameters of $A$, and $\Sigma$ :

$$
-3 T \ln (2 \pi)+(T / 2) \ln \left(|A|^{2}\right)-(T / 2) \ln \left(\left|\Sigma \Sigma^{\prime}\right|\right)-(T / 2)\left\{\left[A^{\prime}\left(\Sigma \Sigma^{\prime}\right)^{-1} A\right] \widehat{\Omega}\right\}
$$


This approach can be employed to estimate both the overidentified case suggested by Equation (9) and the triangular model identified just now (although, in the latter case, the usual approach of Cholesky decomposition for $\widehat{\Omega}$ would yield the same result).

\section{SVAR RESULTS}

Below is a timeline for the official monetary policy regimes pursued by the Bank of England and recessions that took place in the UK:

- July 1976 to April 1979: monetary targeting (M3)

- May 1979 to February 1987: monetary targeting

- 1980Q1 to 1981Q1: recession

- March 1987 to September 1990: informal linking of the pound to the Deutsche mark

- 1990Q3 to 1991Q3: recession

- October 1990 to September 1992: membership in the exchange rate mechanism

- October 1992 to April 1997: inflation targeting prior to the operational independence of the Bank of England

- 2008Q2 to 2009Q2: recession

Running the SVAR analysis for different samples and factoring in the above developments show that the UK data can be split into two samples: an early sample that spans 1978Q3 to 1990Q1 and a recent sample that spans 1993:Q1 to 2011:Q3. We exclude the period in between, since the data are too noisy due to the UK's exchange rate mechanism membership in that period. Similarly, the period after 2011Q3 is not included, because it was a tumultuous time during which unconventional monetary policy tools, such as quantitative easing, were applied.

The estimated monetary policy, money demand, and monetary system equations are provided in Tables 1 to 4 . Tables 1 and 2 provide the regression results for the early sample, with the data as logarithmic levels and growth rates, respectively. Tables 3 and 4 do the same for the recent sample. We use a likelihood ratio test to see whether the inclusion of monetary aggregates in the monetary policy rule improves the fit. ${ }^{6}$ The restriction of excluding the monetary aggregates from the monetary policy rule given by Equation (11) is rejected at the $99 \%$ confidence level for all the samples. The constraint of excluding prices and the output from Equation (11), however, does not decrease the model's fit by much. These results point to a monetary policy rule that includes the monetary aggregates.

${ }_{6}$ The test is conducted by multiplying the difference of the maximized likelihood values with 2, and then comparing it with the critical chi-squared value, for which the degrees of freedom is equal to the number of restrictions. 
Table 1.

Maximum Likelihood Estimates from SVARs Data in Log Levels, Early Sample: 1978:3 - 1990:1

This table presents SVAR analysis results for four different specifications of the monetary policy rule. Standard deviations are in parentheses.

\begin{tabular}{|c|c|c|}
\hline Model & Coefficients & $\begin{array}{c}\text { Other } \\
\text { Estimates }\end{array}$ \\
\hline \multicolumn{3}{|c|}{ Panel A. Triangular Identification } \\
\hline Monetary Policy & $\begin{aligned} R= & 0.11 P-0.19 Y-0.00 C P \\
& (0.26) \quad(0.27) \quad(0.03)\end{aligned}$ & $\begin{array}{c}\mathrm{L}=2856.2 \\
\sigma=0.0070 \\
(0.0004)\end{array}$ \\
\hline Money Demand & $\begin{aligned} \mathrm{M}= & 0.42 \mathrm{P}+0.48 \mathrm{Y}+0.05 \mathrm{R}+0.02 \mathrm{CP} \\
& (0.26) \quad(0.28) \quad(0.15) \quad(0.04)\end{aligned}$ & $\begin{array}{r}\sigma=0.0077 \\
(0.0005)\end{array}$ \\
\hline \multicolumn{3}{|c|}{ Panel B. Interest Rate-Money Rule } \\
\hline Monetary Policy & $\mathrm{R}=2.19 \mathrm{M}$ & $\begin{array}{c}\mathrm{L}=2852.2 \\
\sigma=0.0143 \\
(0.0036)\end{array}$ \\
\hline Money Demand & $\begin{aligned} \mathrm{M}-\mathrm{P}= & 0.88 \mathrm{Y}-11.97 \mathrm{U} \\
& (1.75) \quad(20.43)\end{aligned}$ & $\begin{array}{c}\sigma=0.0873 \\
(0.0708)\end{array}$ \\
\hline Monetary System & $\begin{aligned} \mathrm{U}= & 0.64 \mathrm{R}+0.17(\mathrm{M}-\mathrm{P}) \\
& (0.07) \quad(0.06)\end{aligned}$ & $\begin{array}{c}\sigma=0.0145 \\
(0.0040)\end{array}$ \\
\hline \multicolumn{3}{|c|}{ Panel C. Taylor Rule with Money } \\
\hline Monetary Policy & 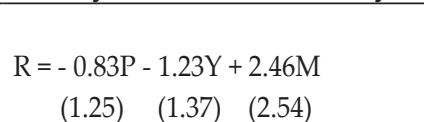 & $\begin{array}{c}\mathrm{L}=2853.7 \\
\sigma=0.0157 \\
(0.0044)\end{array}$ \\
\hline Money Demand & $\begin{aligned} \mathrm{M}-\mathrm{P}= & 0.92 \mathrm{Y}-15.88 \mathrm{U} \\
& (2.17) \quad(48.91)\end{aligned}$ & $\begin{array}{c}\sigma=0.0776 \\
(0.0577)\end{array}$ \\
\hline Monetary System & $\begin{aligned} U= & 0.64 \mathrm{R}+0.16(\mathrm{M}-\mathrm{P}) \\
& (0.08) \quad(0.06)\end{aligned}$ & $\begin{array}{c}\sigma=0.0147 \\
(0.0041)\end{array}$ \\
\hline \multicolumn{3}{|c|}{ Panel D. Taylor Rule without Money } \\
\hline Monetary Policy & $\begin{aligned} R= & 0.11 P-0.18 Y \\
& (0.25) \quad(0.26)\end{aligned}$ & $\begin{array}{c}\mathrm{L}=2823.9 \\
\sigma=0.0070 \\
(0.0004)\end{array}$ \\
\hline Money Demand & 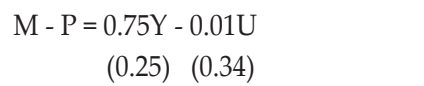 & $\begin{array}{c}\sigma=0.0100 \\
(0.0007)\end{array}$ \\
\hline Monetary System & $\begin{aligned} \mathrm{U}= & 0.46 \mathrm{R}+0.10(\mathrm{M}-\mathrm{P}) \\
& (0.05) \quad(0.05)\end{aligned}$ & $\begin{array}{c}\sigma=0.0050 \\
(0.0005)\end{array}$ \\
\hline
\end{tabular}


Table 2.

Maximum Likelihood Estimates from SVARs Data in Growth Rates, Early Sample: 1978:3 - 1990:1

This table presents SVAR analysis results for four different specifications of the monetary policy rule. Standard deviations are in parentheses.

\begin{tabular}{|c|c|c|}
\hline Model & Coefficients & $\begin{array}{c}\text { Other } \\
\text { Estimates }\end{array}$ \\
\hline \multicolumn{3}{|c|}{ Panel A. Triangular Identification } \\
\hline Monetary Policy & $\begin{aligned} R= & 0.19 P-0.05 Y+0.00 C P \\
& (0.18) \quad(0.18) \quad(0.03)\end{aligned}$ & $\begin{array}{c}\mathrm{L}=1193.2 \\
\sigma=0.0089 \\
(0.0008)\end{array}$ \\
\hline Money Demand & $\begin{aligned} \mathrm{M}= & 0.15 \mathrm{P}+0.14 \mathrm{Y}-0.08 \mathrm{R}-0.01 \mathrm{CP} \\
& (0.19) \quad(0.18) \quad(0.16)\end{aligned}$ & $\begin{array}{c}\sigma=0.0075 \\
(0.0007)\end{array}$ \\
\hline \multicolumn{3}{|c|}{ Panel B. Interest Rate-Money Rule } \\
\hline Monetary Policy & $\mathrm{R}=3.70 \mathrm{M}$ & $\begin{array}{r}\mathrm{L}=1191.3 \\
(0.0113)\end{array}$ \\
\hline Money Demand & 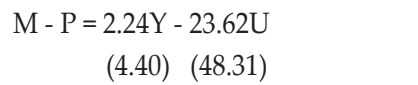 & $\begin{array}{c}\sigma=0.0409 \\
(0.0264)\end{array}$ \\
\hline Monetary System & $\begin{aligned} \mathrm{U}= & 0.66 \mathrm{R}+0.16(\mathrm{M}-\mathrm{P}) \\
& (0.08) \quad(0.06)\end{aligned}$ & $\begin{array}{c}\sigma=0.0099 \\
(0.0027)\end{array}$ \\
\hline \multicolumn{3}{|c|}{ Panel C. Taylor Rule with Money } \\
\hline Monetary Policy & $\begin{array}{rr}\mathrm{R}= & -0.40 \mathrm{P}-0.61 \mathrm{Y}+4.02 \mathrm{M} \\
& (1.07) \quad(1.12) \quad(4.69)\end{array}$ & $\begin{array}{c}\mathrm{L}=1193.2 \\
\sigma=0.0206 \\
(0.0085)\end{array}$ \\
\hline Money Demand & $\begin{aligned} \mathrm{M}-\mathrm{P}= & 2.49 \mathrm{Y}-26.97 \mathrm{U} \\
& (5.84) \quad(70.49)\end{aligned}$ & $\begin{array}{c}\sigma=0.0420 \\
(0.0248)\end{array}$ \\
\hline Monetary System & $\begin{aligned} \mathrm{U}= & 0.68 \mathrm{R}+0.16(\mathrm{M}-\mathrm{P}) \\
& (0.08) \quad(0.06)\end{aligned}$ & $\begin{array}{c}\sigma=0.0099 \\
(0.0027)\end{array}$ \\
\hline \multicolumn{3}{|c|}{ Panel D. Taylor Rule without Money } \\
\hline Monetary Policy & $\begin{aligned} R= & 0.19 P-0.05 Y \\
& (0.18)(0.18)\end{aligned}$ & $\begin{array}{c}\mathrm{L}=1172.9 \\
\sigma=0.0089 \\
(0.0008)\end{array}$ \\
\hline Money Demand & 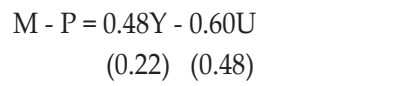 & $\begin{array}{c}\sigma=0.0102 \\
(0.0010)\end{array}$ \\
\hline Monetary System & $\begin{aligned} \mathrm{U}= & 0.43 \mathrm{R}+0.13(\mathrm{M}-\mathrm{P}) \\
& (0.05) \quad(0.05)\end{aligned}$ & $\begin{array}{c}\sigma=0.0050 \\
(0.0006)\end{array}$ \\
\hline
\end{tabular}


Table 3

Maximum Likelihood Estimates from SVARs Data in Log Levels, Recent Sample: 1993:1 - 2011:3

This table presents SVAR analysis results for the recent sample for four different specifications of the monetary policy rule. Standard deviations are in parentheses.

\begin{tabular}{|c|c|c|}
\hline Model & Coefficients & $\begin{array}{c}\text { Other } \\
\text { Estimates }\end{array}$ \\
\hline \multicolumn{3}{|c|}{ Panel A. Triangular Identification } \\
\hline Monetary Policy & $\begin{aligned} \mathrm{R}= & 0.10 \mathrm{P}+0.03 \mathrm{Y}+0.02 \mathrm{CP} \\
& (0.07) \quad(0.10) \quad(0.01)\end{aligned}$ & $\begin{array}{c}\mathrm{L}=1027.5 \\
\sigma=0.0020 \\
(0.0002)\end{array}$ \\
\hline Money Demand & $\begin{aligned} \mathrm{M}= & 0.38 \mathrm{P}-0.24 \mathrm{Y}-0.27 \mathrm{R}+0.03 \mathrm{CP} \\
& (0.19) \quad(0.26)(0.29) \quad(0.02)\end{aligned}$ & $\begin{array}{c}\sigma=0.0050 \\
(0.0005)\end{array}$ \\
\hline \multicolumn{3}{|c|}{ Panel B. Interest Rate-Money Rule } \\
\hline Monetary Policy & $\begin{aligned} R= & 0.62 M \\
& (0.30)\end{aligned}$ & $\begin{array}{c}\mathrm{L}=1021.7 \\
\sigma=0.0074 \\
(0.0079)\end{array}$ \\
\hline Money Demand & $\begin{array}{r}\mathrm{M}-\mathrm{P}=-0.21 \mathrm{Y}-12.81 \mathrm{U} \\
(0.63)\end{array}$ & $\begin{array}{c}\sigma=0.0171 \\
(0.0084)\end{array}$ \\
\hline Monetary System & $\begin{array}{c}\mathrm{U}=0.51 \mathrm{R}+0.06(\mathrm{M}-\mathrm{P}) \\
\quad(0.06) \quad(0.02)\end{array}$ & $\begin{array}{c}\sigma=0.0083 \\
(0.0052)\end{array}$ \\
\hline \multicolumn{3}{|c|}{ Panel C. Taylor Rule with Money } \\
\hline Monetary Policy & 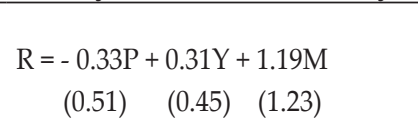 & $\begin{array}{c}\mathrm{L}=1022.5 \\
\sigma=0.0426 \\
(0.3015)\end{array}$ \\
\hline Money Demand & $\begin{array}{r}M-P=- \\
\quad 0.27 Y-21.12 U \\
(0.97) \quad(18.57)\end{array}$ & $\begin{array}{c}\sigma=0.0148 \\
(0.0066)\end{array}$ \\
\hline Monetary System & $\begin{aligned} \mathrm{U}= & 0.55 \mathrm{R}+0.04(\mathrm{M}-\mathrm{P}) \\
& (0.07) \quad(0.03)\end{aligned}$ & $\begin{array}{c}\sigma=0.0086 \\
(0.0053)\end{array}$ \\
\hline \multicolumn{3}{|c|}{ Panel D. Taylor Rule without Money } \\
\hline Monetary Policy & $\begin{aligned} R= & 0.10 P+0.04 Y \\
& (0.08) \quad(0.10)\end{aligned}$ & $\begin{array}{c}\mathrm{L}=1019.1 \\
\sigma=0.0020 \\
(0.0002)\end{array}$ \\
\hline Money Demand & $\begin{array}{r}M-P=-0.13 Y-1.10 U \\
(0.25) \quad(0.34)\end{array}$ & $\begin{array}{c}\sigma=0.0055 \\
(0.0006)\end{array}$ \\
\hline Monetary System & $\begin{aligned} \mathrm{U}= & 0.32 \mathrm{R}+0.02(\mathrm{M}-\mathrm{P}) \\
& (0.04) \quad(0.02)\end{aligned}$ & $\begin{array}{c}\sigma=0.0023 \\
(0.0005)\end{array}$ \\
\hline
\end{tabular}


Table 4.

Maximum Likelihood Estimates from SVARs Data in Growth Rates, Recent Sample: 1993:1 - 2011:3

This table presents SVAR analysis results for the recent sample for four different specifications of the monetary policy rule. Standard deviations are in parentheses.

\begin{tabular}{lcc}
\hline Model & Coefficients & Other \\
Estimates
\end{tabular}


The results in Tables 1 to 4 suggest that variables other than the money stock (i.e., the output and prices) do not enter the monetary policy equation significantly. Therefore, there is little support for a Taylor rule depiction of the UK's monetary policy in either sample period. Instead, the interest rate-money rule is the preferred specification. The estimates suggest that the interest rate responds positively to increasing levels of the money stock. Money demand usually increases with income levels, and the user cost of money increases with interest rates. As one would expect, money demand falls when the cost of money increases.

An important difference between the early and recent samples is the reaction of the interest rate to the stock of money, as can be seen from the monetary policy equations. The coefficient on the money stock is much larger in the early sample than in the recent sample. However, in terms of significance, the coefficient on the money stock in the monetary policy equation fares better after 1993.

Figures 3 and 4 illustrate the impulse responses in percentage points to onestandard-deviation monetary policy shocks. Since the interest rate-money rule is the preferred specification, the impulse responses from the interest rate-money rule are compared to those obtained from the triangular model.

Figure 3.

\section{Early Sample Impulse Responses to One-standard Deviation Monetary Policy Shock}

This figure shows the responses of short-term nominal interest rate, money, real GDP, and price level to a onestandard deviation monetary policy shock. Panels (a) and (b) use data in logarithmic form whereas panels (c) and (d) use the growth rate of variables. Panels (a) and (c) use triangular identification whereas panels (b) and (d) use interest rate-money rule to characterize the monetary policy.
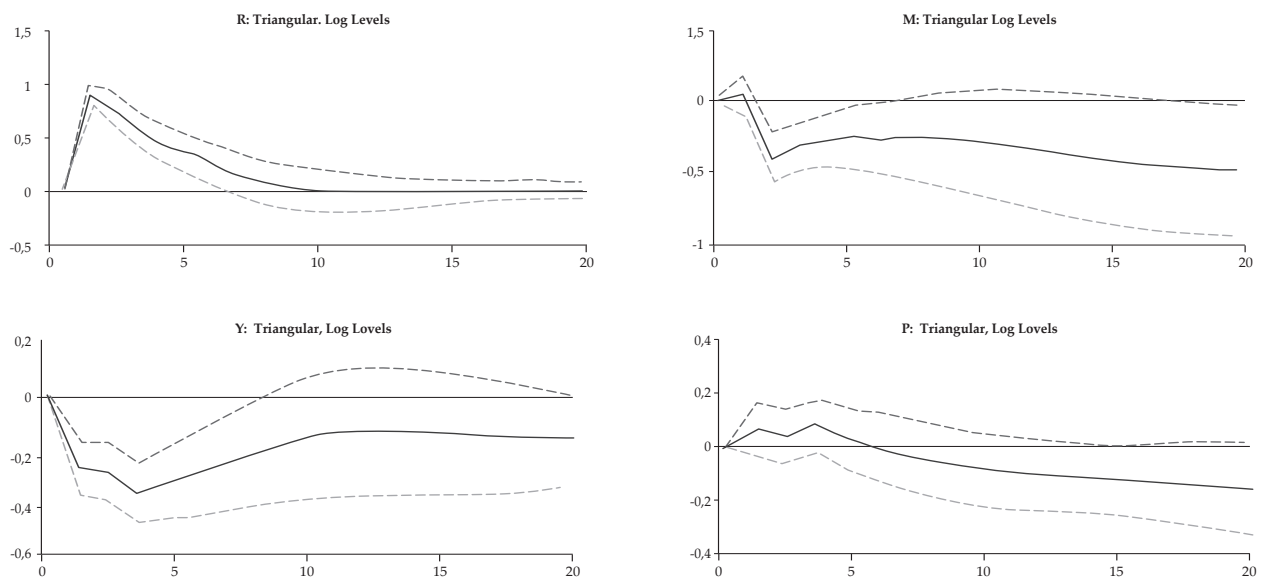

(a) Triangular, log level
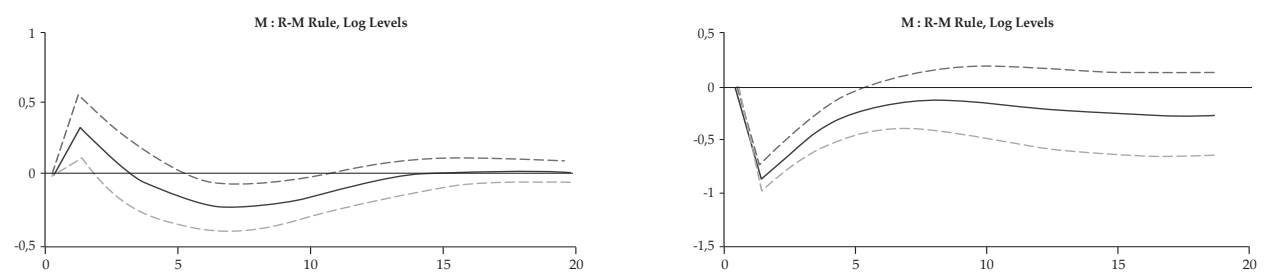
Figure 3.

Early Sample Impulse Responses to One-standard Deviation Monetary Policy Shock (Continued)
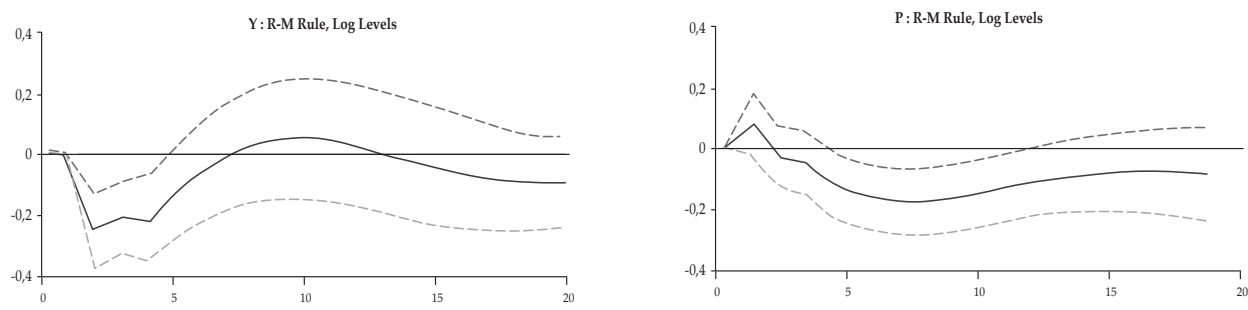

(b) R-M rule, log level
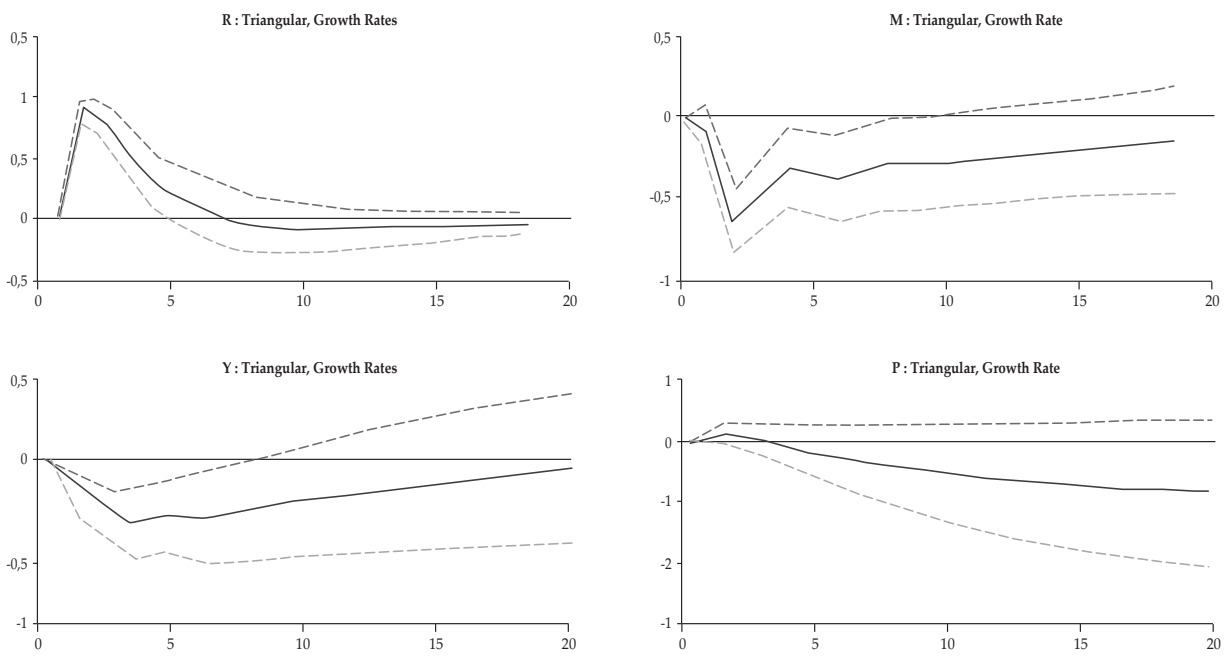

(c) Triangular, growth rates
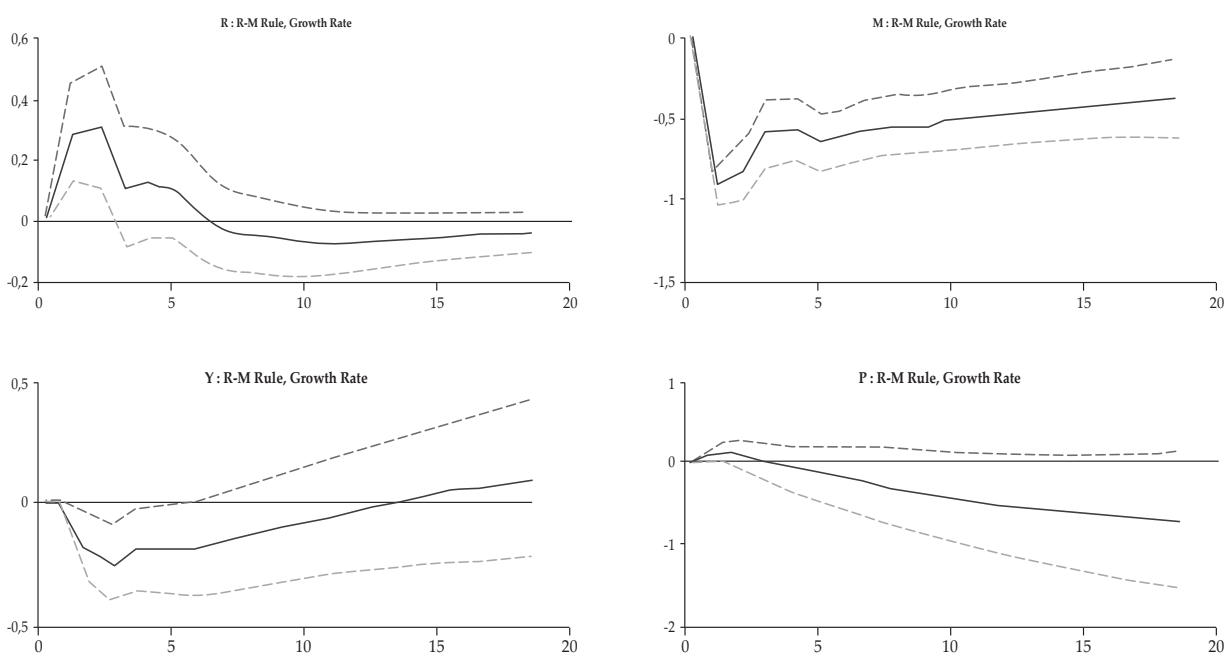

(d) R-M rule, growth rates 
Figure 4.

\section{Recent Sample Impulse Responses to One-standard Deviation Monetary Policy Shock}

This figure shows the responses of short-term nominal interest rate, money, real GDP, and price level to a onestandard deviation monetary policy shock. Panels (a) and (b) use data in logarithmic form whereas panels (c) and (d) use the growth rate of variables. Panels (a) and (c) use triangular identification whereas panels (b) and (d) use interest rate-money rule to characterize the monetary policy.
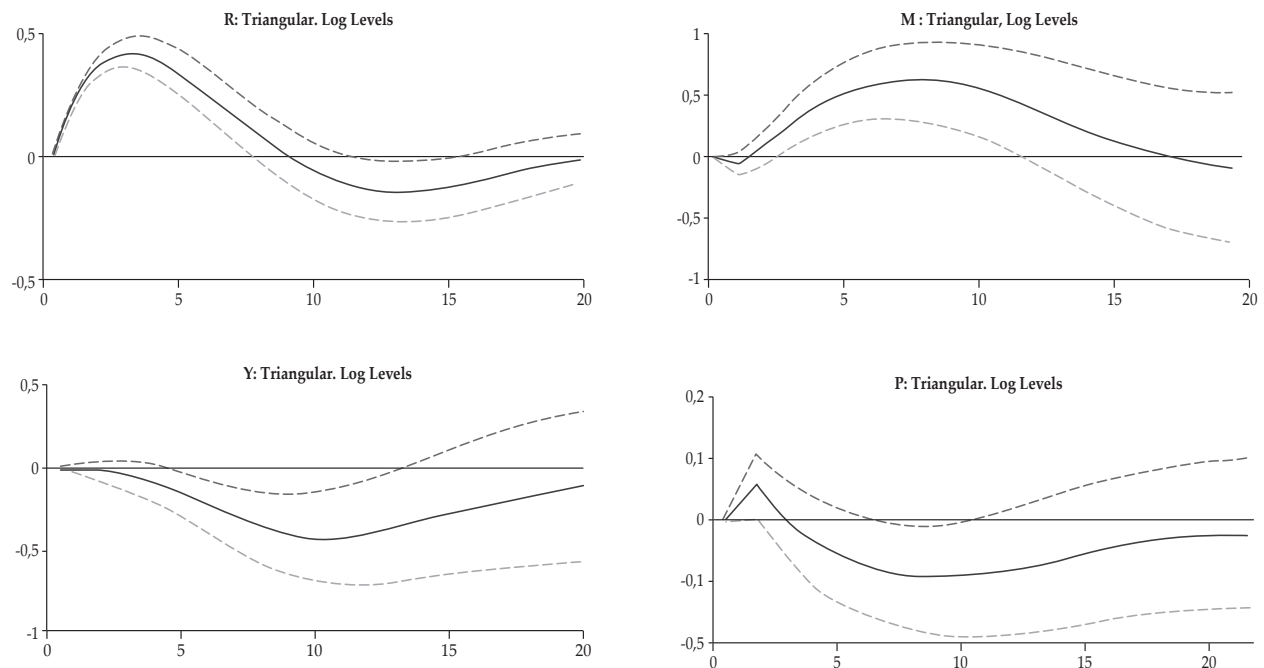

(a) Triangular, log level
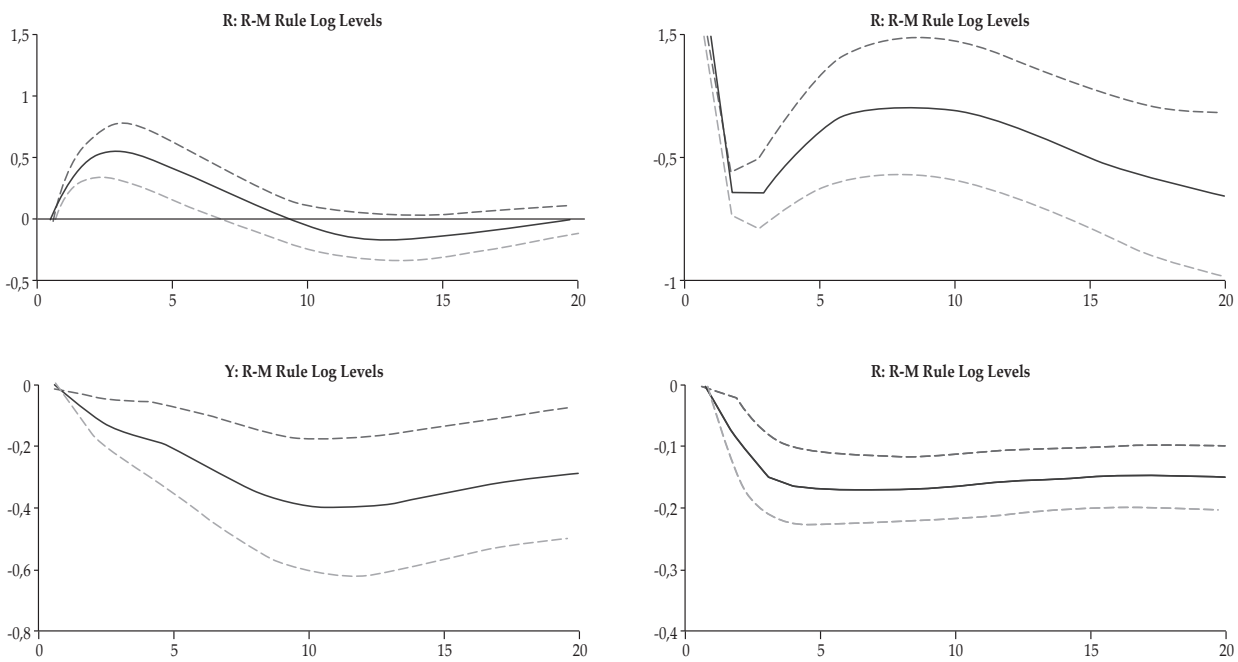

(b) R-M rule, log level 


\section{Figure 4.}

\section{Recent Sample Impulse Responses to One-standard Deviation Monetary Policy Shock (Continued)}
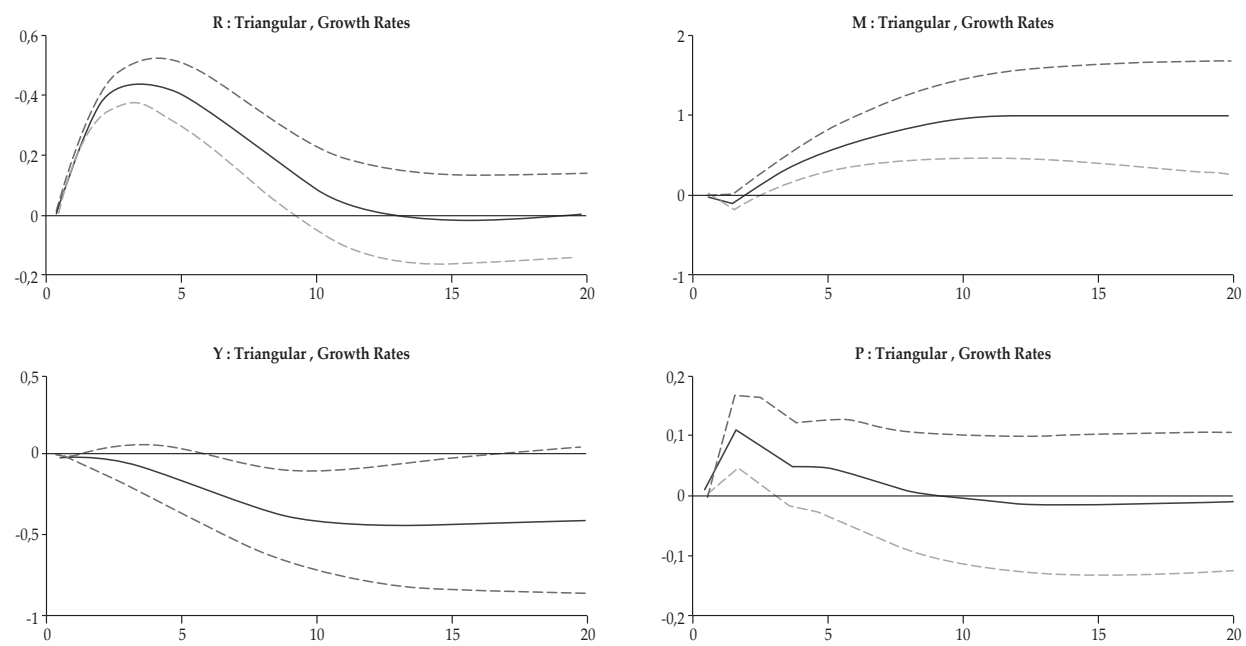

(c) Triangular, growth rates
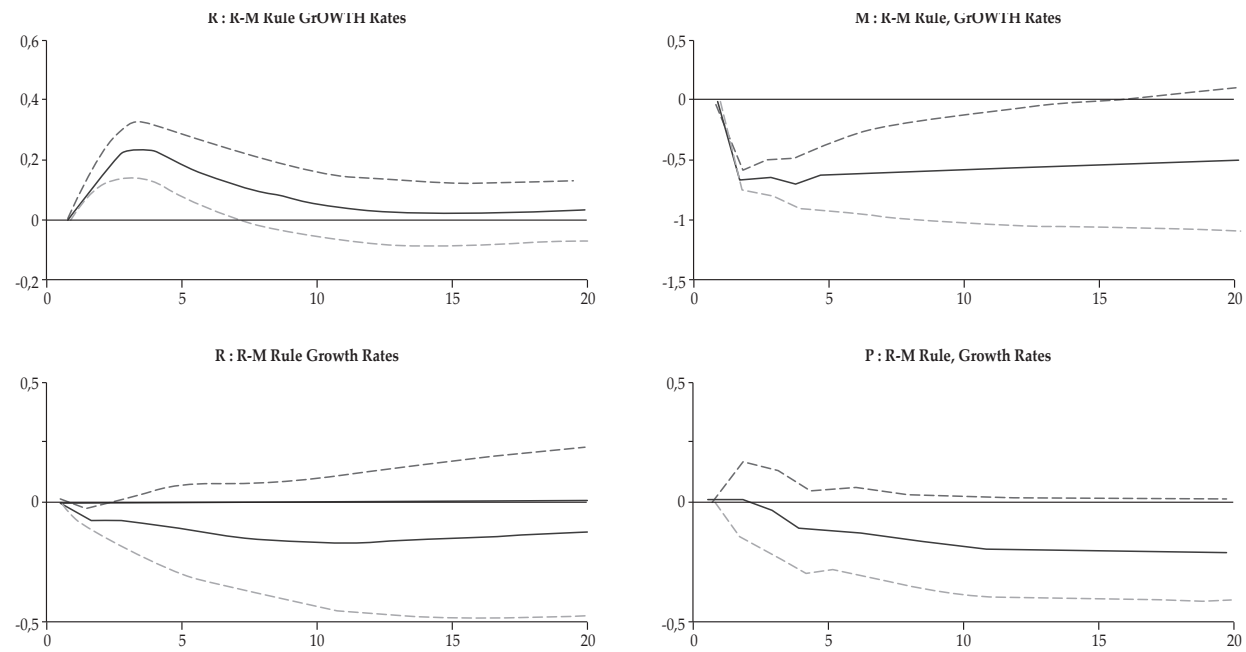

(d) R-M rule, growth rates

Two established puzzles in the VAR literature need to be addressed. Following a positive shock to the interest rate, it is common to observe an increase in the price level (price puzzle) and an increase in the money stock (liquidity puzzle) in empirical models, which is inconsistent with the theory. The estimated monetary policy rules for both samples suggest that the incorporation of monetary aggregates into the monetary policy rule helps resolve both puzzles, and, following a monetary policy shock, price levels and monetary aggregates behave in line with what macroeconomic theory suggests. 


\section{CONCLUSION}

It is very important to successfully gauge the stance of monetary policy and understand the mechanisms through which it affects the variables in the economy. To achieve these goals, we can use the money stock as an alternative or complementary measure to short-term nominal interest rates, as long as the stock of money is properly measured.

The study starts with constructing the Divisia index for the UK for the period between 1978 and 2011. We use SVAR to estimate the monetary policy equation for the early and recent samples. The results show little support for a Taylor rule depiction of UK monetary policy and suggest the interest rate-money rule as the preferred formulation for the conduct of monetary policy. Including the (correct) measure of the quantity of money in the monetary policy equation and disentangling the money supply from the money demand resolve the price and liquidity puzzles, two well-established puzzles in the VAR literature. Furthermore, this study shows that the reaction of the interest rate to the stock of money was quite strong for the period between 1978 and 1990, but this relation weakens from 1993 onward. The findings of this paper point to the informational content embedded in monetary aggregates and suggest that these should be taken into account when evaluating monetary policy.

\section{REFERENCES}

Anderson, R., Duca, J., Fleissig, A., and Jones, B. (2019). New Monetary Services (Divisia) Indexes for the Post-War US. Journal of Financial Stability, 42, 3-17.

Barnett, W. (1980). Economic Monetary Aggregates: An Application of Index Number and Aggregation Theory. Journal of Econometrics, 14, 11-48.

Belongia, M. (1996). Measurement Matters: Recent Results from Monetary Economics Reexamined. Journal of Political Economy, 104, 1065-1083.

Belongia, M. and Ireland, P. (2015). Interest Rates and Money in the Measurement of Monetary Policy. Journal of Business \& Economic Statistics, 33, 255-269.

Belongia, M. and Ireland, P. (2016). Money and Output: Friedman and Schwartz Revisited. Journal of Money, Credit and Banking, 48, 1223-1266.

Belongia, M. and Ireland, P. (2019). The Demand for Divisia Money: Theory and Evidence. Journal of Macroeconomics, 61, 1-24.

Bernanke, B. and Blinder, A. (1992). The Federal Funds Rate and the Channels of Monetary Transmission. American Economic Review, 82, 901-921.

Bissoondeeal, R., Jones, B., Binner, J., and Mullineux, A. (2010). Household-sector Money Demand for the UK. The Manchester School, 78, 90-113.

Darvas, Z. (2015). Does Money Matter in the Euro Area? Evidence from a New Divisia Index. Economics Letters, 133, 123-126.

Dery, C. and Serletis, A. (2019). Interest Rates, Money, and Economic Activity. Macroeconomic Dynamics, 1-50.

Drake, L., Mullineux, A., and Agung, J. (2000). Incorporating Risky Assets in Divisia Monetary Aggregates. Bulletin of Monetary Economics and Banking, 3, $1-23$.

Estrella, A. and Mishkin, F. (1997). Is There a Role for Monetary Aggregates in the Conduct of Monetary Policy? Journal of Monetary Economics, 40, 279-304. 
Friedman, M. and Schwartz, A. (1963). Money and Business Cycles. Review of Economics and Statistics, 45, 32-64.

Hancock, M. (2005). Divisia Money. Bank of England Quarterly Bulletin, Spring.

Hamilton, J. (1994). Time Series Analysis. Princeton: Princeton University Press.

Hendrickson, J. (2014). Redundancy or Mismeasurement? A Reappraisal of Money. Macroeconomic Dynamics, 18, 1437-1465.

Hendrickson, J. (2017). An Evaluation of Friedman's Monetary Instability Hypothesis. Southern Economic Journal, 83, 744-755.

Hodrick, R. and Prescott, E. (1997). Postwar US Business Cycles: An Empirical Investigation. Journal of Money, Credit, and Banking, 29, 1-16.

Keating, J., Kelly, L., Smith, A., and Valcarcel, V. (2019). A Model of Monetary Policy Shocks for Financial Crises and Normal Conditions. Journal of Money, Credit, and Banking, 50, 227-259.

King, R. and Plosser, C. (1984). Money, Credit, and Prices in a Real Business Cycle. The American Economic Review, 74, 363-380.

Leeper, E. and Roush, J. (2003). Putting 'M' Back in Monetary Policy. Journal of Money, Credit and Banking, 35, 1217-1256.

Lutkepohl, H. (2006). New Introduction to Multiple Time Series Analysis. Berlin: Springer-Verlag.

Mishkin, F. (2007) The Economics of Money, Banking, and Financial Markets. Boston: Pearson Education.

Plosser, C. (1989). Understanding Real Business Cycles. The Journal of Economic Perspectives, 3, 51-77.

Sims, C. (1980). Macroeconomics and Reality. Econometrica, 48, 1-48.

Sims, C. (1986). Are Forecasting Models Usable for Policy Analysis? Federal Reserve Bank of Minneapolis Quarterly Review, 111, 2-16.

Stock, J. and Watson, M. (1999). Forecasting Inflation. Journal of Monetary Economics, 44, 293-335.

Woodford, M. (2003). Interest and Prices: Foundations of a Theory of Monetary Policy. Princeton: Princeton University Press. 
This page is intentionally left blank 